\title{
THE CONCEPT OF CORPORATE SOCIAL RESPONSIBILITY IN ISLAMIC LAW
}

\author{
Salma Taman \\ INTRODUCTION
}

This Article analyzes whether the concept of corporate social responsibility (CSR) is consistent with Islamic law (Sharia). The goal is to survey the primary sources of Sharia in an attempt to find any Islamic notions, Quranic verses, or Prophetic Hadiths that are related to CSR and that show that it is supported by and consistent with Islamic law.

Part I discusses the concept of CSR and what it represents in the West by comparing the most widely accepted definitions of CSR. After determining what constitutes CSR, the Article explores whether CSR exists in Islamic law. The analysis of whether CSR is consistent with Islamic law is done via a discussion of two jurisprudential tools. Eminent Muslim jurists, who were confronted with questions relating to Sharia that had no direct answers in the primary sources, created these tools. They came up with jurisprudential solutions to make Islamic law more flexible, capable of accommodating the rapidly changing world, and able to provide answers to any new notions that were not existent during the legislation process of Sharia.

After showing that CSR is consistent with Sharia, in Parts II-IV, the Article looks more closely at Islamic law to extract any ideas, notions, or concepts that indicate CSR is required by the Sharia. The Article then briefly explains these notions and shows the Quranic verses and Prophetic Hadiths that embody them. Part V discusses prohibited commercial activities in Islamic law, including usury, gambling, gharar, and others. This section provides definitions for each activity as well as the reasons for its prohibition. Part VI introduces Islamic financial institutions (IFIs), the reasons for their existence, and the services they offer as alternatives to the prohibited activities in Islamic law. Part VII discusses some implications of the prohibitions for doing business in and with Islamic countries in the $21^{\text {st }}$ century. Part VIII offers concluding remarks.

\section{THE CONCEPT OF CSR}

The definition of CSR is a work in progress. There is not a perfect definition upon which everyone would agree. However, several attempts

* The author is fluent in both Arabic and English. She is also a devout Muslim. All Quranic verses and citations to Bahkari within this article are the author's personal translations. The editors of the Indiana International \& Comparative Law Review relied upon the accuracy of the author's translations. 
provide a good idea of what CSR is truly about. The European Commission defines CSR as "a concept whereby companies integrate social and environmental concerns in their business operations and in their interactions with their stake holders on a voluntary basis." Others define CSR as "the continuing commitment by business to behave ethically and contribute to economic development while improving the quality of life of the workforce and their families as well as of the local community and society at large." Although there are many other definitions, these two definitions give a good overview of what CSR is generally thought to be.

CSR, a concept that is generally assumed to have been born in the West, is nothing more and nothing less than a measure of the civilization and development of a nation. It is a notion about which third world countries have little idea and over which first world countries compete. Milton Friedman's opinion that corporations have no responsibility toward society other than legally maximizing their profits ${ }^{3}$ is no longer valid. Many corporations now have financial resources that are as vast as those of some entire societies. They control the markets and the wealth of the nations in which they operate. Exempting them from responsibilities other than making profits for their shareholders would mean that real development of those nations would be marginalized and the circulation of wealth would be forever limited to the higher levels of society. Without a commitment to CSR, corporations would operate in a deteriorating natural environment with rising levels of poverty, ultimately causing declining purchasing power of their own customers. Can corporations function, let alone thrive, in an environment where everything else is stagnating or collapsing? Obviously not. It is, indeed, in the interest of all corporations to be socially responsible and to give back to society in a measure equal to what they are taking, if not more.

Even from a business perspective, it makes sense for corporations to be socially responsible. With the growing importance of CSR, it has become a factor in the competitive race; it has become a way of outsmarting the competition. Corporations can get away with making high profits and paying little in taxes-even with products that are not necessarily very good-if they are socially responsible and environmentally friendly.

\section{CSR IN ISLAM}

Although the term corporate social responsibility was coined in the

1. Commission Green Paper Promoting a European Framework for Corporate Social Responsibility, at $\uparrow 20$, COM (2001) 366 final (July 18, 2001).

2. Phil Watts et al., World Business Council for Sustainable Development, MEETING Changing EXPECTATIONS: Corporate SOCIAL ResPonsibility 3 (1999), http://www.wbcsd.org/DocRoot/hbdf19Txhmk3kDxBQDWW/CSRmeeting.pdf.

3. MiLTON FriedMAN, CapitalisM AND FrEedom 133 (40th Anniv. ed. 2002). 
West, CSR is not an exclusively Western notion. It is true that there is nothing in the Islamic faith or law that dictates that "corporations" should be "socially responsible" in those terms. But, what does it mean to be socially responsible? From the two previously mentioned definitions and other similar ones, CSR means conducting your business while preserving the environment, treating your workers well, being fair to your competitors, being honest and just in your dealings, caring about society and its less fortunate members, and looking after all stakeholders' interests without undermining those of the shareholders.

If this is what CSR is, then the notion of CSR lies at the very heart of the Islamic faith and law. Properly understood, CSR is not a recommendation, but rather an obligation for every Muslim. It is fascinating how Sharia, although quite ancient, includes detailed rules about commerce and the appropriate conduct of traders and other business persons. Before going into the details of CSR under Sharia, it is useful to briefly explain what is considered Sharia and what is not.

A brief discussion of the sources of law and their hierarchy is necessary. Sharia refers to "the sum of legal rules that God has legislated and sent to the people through Muhammad (P). $\left[{ }^{4}\right]$ Sharia is incorporated in Quran[ $\left.{ }^{5}\right]$ and Sunnah., ${ }^{, 6}$ The legislative process of Islamic law took place only during the lifetime of Muhammad (P). Only he was allowed to legislate because only he was divinely inspired by God. The only sources of Sharia are the Quran and Sunnah. Any scholarly opinions or rules provided by the companions or followers of Muhammad (P) are not part of Sharia. The rules and opinions of scholars, legislators, and leaders after Muhammad (P), no matter how eminent such scholars and leaders are or were, are not part of Sharia. In the Islamic faith, scholars and religious leaders-let alone worldly leaders-are not considered divinely inspired. They may be wise. They may be well intentioned; but they are as fallible as other human beings. Their rules are worldly rules and not Sharia. ${ }^{7}$

Scholarly opinions about Islamic law fall under the category of Fiqh, which is different from Sharia. Fiqh literally means knowledge or comprehension. In the context of Islamic law, Fiqh means knowledge of the practical legal rules that enable Muslims to conduct their lives according to the teachings of Islam. This knowledge is based on the Quran and

4. "(P)" is an abbreviation for "pbuh," which means "peace be upon him."

5. The Quran is the record of the revelations that were sent to Mohamed from God through the Angel Gabriel. Muslims believe that the Quran is the actual word of God; thus, the Quran is the first and most important source of Islamic Law.

6. Ramadan El Shoroumbassy, Al MadKhal le dirassat Al FiQH Al Islamy [ThE INTRODUCTION TO ISLAMIC JURISPRUDENCE] 5 (2003) (explaining that the Sunnah is the collection of sayings and actions of the Prophet Muhammad and that sayings of the Prophet Muhammad are also known as Hadith(s)).

7. Id. at 12 . 
Sunnah but is different from these legislative sources. ${ }^{8}$ In sum, Sharia is the divine law, and Fiqh is the human interpretation and attempt at application of Sharia. ${ }^{9}$

Whereas Sharia sets general limits, Fiqh supplements the details to the more general rules stipulated in Sharia. Logically, any detailed rules provided by Fiqh cannot be inconsistent with any general principle set by Sharia. However, while Sharia is static, Fiqh is dynamic, evolving over time. Therefore, one can say that Figh is not only the way Sharia can be understood. It is also applicable to more issues and situations in life and is able to accommodate change to keep Sharia timely and comprehensible in different eras and places. ${ }^{10}$

This author emphasizes the distinction between Sharia (law) and Fiqh (jurisprudence) because it is supremely important to clarify that scholarly opinions about the correct interpretation and application of Sharia, although often well respected and appreciated, are not binding on Muslims. The sole exception is in the case of ljma, when there is a consensus of opinion of all well-respected scholars of a certain time and age on a certain matter that was left unresolved by the Quran and Sunnah. Since scholars base their opinions on their knowledge and understanding of the Quran and Sunnah, if they unanimously agree on a matter, it is not likely that all of them are wrong. After all, they are the people with the best knowledge of the law and its two divine sources. However, Ijma is quite rare. So, this Article remains focused on CSR in the law that is binding on all Muslims; that is, the Quran and Sunnah, rather than the non-binding Fiqh.

The next section examines the Quran and Sunnah to identify the most important Quranic verses and Prophetic sayings (Hadiths) and activities that reflect the concept of CSR. It will explore the obligations of Muslims that reflect the notion of CSR as it has been previously defined.

\section{CSR AND THE QURAN}

For Muslims, the Quran is the code of ethics that each must follow in his or her personal life as well as in business dealings. Different interpretations of some verses, however, frequently cause confusion and misunderstanding. The following verses are not exhaustive; they are merely examples of the verses that deal with business ethics in Islam.

8. See id. at 5 .

9. Id. Fiqh also provides the more specific substantive legal rules in areas such as: issues related to the proper worship of God (rules for prayer, fasting, etc.); criminal law (details about crimes and punishments); contract law (rules for sales and purchase transactions, settling of debts, etc.); family and personal law (rules about marriage, divorce, child support, etc.); and peace and war issues, including rules on international agreements.

10. Arskal Salim, Challenging the Secular State: The Islamization of Law in Modern Indonesia 12 (2008). 
Interpretations are provided along with the most significant passages from the Quran and Sunnah.

"Righteousness is not turning your faces towards the east or the west (in Prayers). Righteous are those who believe in GOD, the Last Day, the angels, the scripture, and the prophets; and they give the money, cheerfully, to the relatives, the orphans, the needy, the travelers (strangers), the beggars, and to free the slaves; and they observe the Contact Prayers (Salat) and give the obligatory charity (Zakat); and they keep their word whenever they make a promise; and they steadfastly persevere in the face of persecution, hardship, and war. These are the truthful; these are the righteous." Quran [2:177]

"The believing men and women are allies of one another. They advocate righteousness and forbid evil, they observe the Contact Prayers (Salat) and give the obligatory charity (Zakat), and they obey GOD and His messenger. These will be showered by GOD's mercy. GOD is Almighty, Most Wise." Quran [9:71]

"GOD advocates justice, charity, .... And He forbids evil, vice, and transgression. He enlightens you, that you may take heed." Quran [16:90]

"Do you know who really rejects the faith? That is the one who mistreats the orphans. And does not advocate the feeding of the poor. And woe to those who observe the contact prayers (Salat)-who are totally unmindful of their prayers. They only show off. And they prevent charity." Quran [107:1-7]

\section{A. CSR in the Sunnah}

The Prophet said of himself, "I have been sent only for the purpose of perfecting good morals" (Bukhari). The use of the term "only" shows the great importance placed on good morals in Islam.

\section{B. Maquasid Al Sharia (The Purposes of Sharia)}

The Prophet Muhammad's (P) death completed the legislative process in Islamic law. Thus, it is impossible to find clear and certain answers to legal questions that appeared after that period. Once Muhammad (P) died and no more Quranic verses were forthcoming, the only way to figure out how to deal with new challenges and problems has been for Muslim scholars to create new tools that help them discover what the Quran was intended to convey and what the Prophet Muhammad (P) would have advised. Such tools are all based upon general principles provided for in the Quran but not directly addressed by its verses or by the Prophetic Sunnah.

Maquasid Al Sharia is one tool that helps solve many legal questions in Islamic law. In practice, when facing a new legal question, such as whether the concept of CSR is consistent with Islamic law, a Muslim 
checks whether the concept is consistent with the purposes of Sharia. If it is, then CSR would have been encouraged by the Quran and Sunnah, had the question come up during the time of Islamic legislation. This notion of Maquasid Al Sharia, no doubt, is an essential ingredient for making Islamic law flexible and capable of accommodating the rapid change in our modern societies. ${ }^{11}$

But what are the purposes of Sharia, and how do we know whether a certain notion is allowed or even encouraged under Islamic law? Over time, Muslim scholars have surveyed the Quran and Sunnah and concluded that there is a set of main purposes that God intended for Sharia. These underlying purposes include providing for the well-being of humans, diminishing hatred and disputes, and setting limits to human freedom, which generally ends where the freedoms of others start. ${ }^{12}$ The purposes of Sharia also include eliminating hardship and protecting the Earth's population. Last, but most important, is the purpose of promoting justice. Justice is the main pillar of Islamic law. The Quran repeatedly emphasizes that there is no justification for Muslims ever to turn away from justice. ${ }^{13}$ One of the main Muslim convictions is that the pursuit of justice is the only way to eternal peace. ${ }^{14}$

"O believers! Be steadfast for the sake of Allah and bear true witness and let not the enmity of a people incite you to do injustice; do justice; that is nearer to piety. Fear Allah, surely Allah is fully aware of all your actions." Quran [5:8]

"God commands you [people] to return things entrusted to you to their rightful owners, and, if you judge between people, to do so with justice." Quran $[4: 58]^{15}$

CSR and Sharia agree that while a corporation has the freedom to pursue profits, such freedom ends at the point where the freedom of others and the well-being of the environment conflict with this pursuit. Therefore, if CSR promotes the welfare of humankind and the reduction of hardship by a wider circulation of the wealth of nations to include all levels of society, it is consistent with Sharia. If CSR promotes good morals in commercial dealings as part of its promotion of justice between all members of society, then it is, without any doubt, consistent with Sharia and, in fact, central to it.

11. Asyraf Wajdi Dusuki \& Nurdianawati Irwani Abdullah, Maqasid al-Shari ah, Maslahah, and Corporate Social Responsibility, 24:1 AM. J. IsLAMIC SoC. SCI. 25, 31 (2007).

12. Jawed Akhtar Mohammed, Corporate Social Responsibility in Islam 60 (2007) (unpublished Ph.D. dissertation, Auckland University of Technology) (on file with the Auckland University Library).

13. Id.

14. See Gurpreet Singh \& Shiv Sharma: Philosophy of Islam 48-50 (2002).

15. Additional verses from the Quran discussing justice are found at: 4:135, 57:25, $4: 112$, and 5:42. 


\section{Al Masaleh al Mursala (Considerations of Public Interest)}

Another tool Muslim scholars use to answer new questions is the notion of "Al Masaleh al Mursala." Literally, Masaleh means "interests" or "benefits," and Mursala means "free of restrictions." Al Immam Al Ghazali, a very well respected Islamic scholar, established the doctrine of Masaleh Mursala in his quest for solutions to new economic, social, and political questions that arose with the development of Islamic society. Masaleh Mursala refers to all new ideas that have neither been permitted nor prohibited by one or more of the agreed-upon sources of Islamic law. In judging whether an idea or solution is approved according to Masaleh Mursala, scholars look to whether it promotes social welfare. If a certain idea brings benefits to society, it is permitted. If it does more harm than good, it is prohibited. ${ }^{16}$ of course, benefit, social welfare, and public interest are all soft terms. In many ways, they are relative, not absolute. So what constitutes the public interest?

To overcome this problem, Imam Ghazaly ${ }^{17}$ established what are today known as The Five Essentials (Al Daruriat Al Khams). These became the objective criteria for scholars to determine whether an idea or solution promotes the public interest. According to Imam Ghazaly, Masaleh (benefits) are only those that aim to protect one or more of the following five essentials: 1) Protecting Lives, 2) Protecting Lineage, 3) Protecting Religion, 4) Protecting Intellect, and 5) Protecting Property. ${ }^{18}$

Masaleh is one of the most essential vehicles for the development of Islamic law. It helps greatly with the resolution of new questions if a certain question arises and is not directly answered in the Quran or Sunnah or by Ijma. If there is a conflict between benefits to some and harm to others, the rule deduced through Masaleh Mursala should achieve a significant public interest or benefit to the majority of the people. Further, the rule must be logical and must not contradict the principles of the Quran, Sunnah, and the overall spirit of Sharia.

Muslim responses to concepts such as foreign investment, communism, and political or economic boycotts have all been developed according to the notion of Masaleh Mursala. Because it aims at accommodating changing times and societies, rules deduced through Masaleh Mursala can change when social needs and interests change. Since

16. S. M. Ghazanfar \& A. Azim Islahi, Economic Thought of an Arab Scholastic: Abu Hamid al-Ghazali (AH450-505/1058-1111AD), in MedieVAL IsLAMIC ECONOMIC THOUGHT: FILLING THE "GREAT GAP" IN EUROPEAN ECONOMICS 23-44 (S. M. Ghazanfar ed., 2003).

17. See generally JAMES NAIFY, Al-Ghazali, in THE PIMLiCo History of WeSterN PHILOSOPHY 163 (Richard H. Popkin ed., 1999) (providing background information on this important Muslim scholar). See also W. Montgomery WatT, THE Faith AND Practice of AL-GHAZALI (1951).

18. See M. H. Kamali, Principles of Islamic JurisprudenCe 238 (3d ed. 2003). 
the concept of CSR aims at developing the environment where corporations conduct their business, it follows that it "brings benefits and eliminates harm." It is one of these Masaleh Mursla issues not mentioned in the Quran or Sunnah but consistent with Sharia because it achieves a certain benefit for society.

The conclusion to be drawn is that the concept of CSR is consistent with Sharia. Having established this, the next section demonstrates that CSR does not contradict but is central to Sharia. Although not mentioned in the Quran or Sunnah, the substance of CSR is really the essence of the Islamic faith and law. In fact, many, if not all, concepts and ideas represented by CSR lie at the heart of Sharia. CSR requires corporations to be good citizens, which is the essence of Sharia.

\section{Al Zakah}

The word Zakah literally means purification. ${ }^{19}$ In practice, Zakah is an amount of money paid by Muslims at the end of the year as an obligatory donation to the needy, in particular orphans, widows, and the elderly, who can no longer work and provide for themselves. ${ }^{20}$ Wealth is believed to be purified from the hatred and jealousy of the less fortunate on the one hand and the selfishness and arrogance of the wealthy on the other hand, after a percentage of it has been spent on good causes. ${ }^{21}$ Zakah is one of the five fundamental pillars of Islam, ${ }^{22}$ and its observance distinguishes true believers from mere nominal Muslims.

"You shall observe the Contact Prayers (Salat) and give the obligatory charity (Zakat), and bow down with those who bow down." Quran [2:43]

"You cannot attain righteousness until you give to charity from the possessions you love. Whatever you give to charity, GOD is fully aware of." Quran, [3:92].

Muslim society is divided into halves: one half is obligated to give Zakah and the other entitled to take it. What determines whether a Muslim belongs to the half that gives or the half that takes is whether he or she possesses the Nisab. ${ }^{23}$ When a Muslim has enough to cover the essential

19. EgBert Harmsen, Islam, Civil SOcIety and Social Work: Muslim Voluntary WELFARE AsSOCIATIONS IN JORDAN BETWEEN PATRONAGE AND EMPOWERMENT 174 (2008).

20. Among the common English translations of the word Zakah are alms, mandatory charity, and obligatory donation.

21. Quran 9:103 ("Take from their money a charity to purify them and sanctify them. And encourage them, for your encouragement reassures them. GOD is Hearer, Omniscient.").

22. HARMSEN, supra note 19.

23. Virginia B. Morris \& Brian D. Ingram, Guide to Understanding Islamic INVESTING IN ACCORDANCE WITH ISLAMIC SHARIAH 12 (2001). 
needs for himself and his family over a year, he is in possession of the Nisab. If he has more, he is obliged to give Zakah on the excess. The requirement of the $\mathrm{Nisab}^{24}$ was designed to prevent needy Muslims, who are not wealthy enough to provide for their families from burdening themselves with extra expenses to please God. Zakah is only paid from the extra wealth that has not been used or needed for a whole year. ${ }^{25}$ Zakah is one of the clearest manifestations of CSR in Islam. The importance that God has placed on Zakah in the Quran demonstrates how strongly Islam is associated with CSR. Namely, there shall be no profit without paying back to society. Where there is excessive wealth, beyond the essential needs of an owner, there is an obligation to give and to share.

The Quranic verses also specify to whom Zakah shall be paid:

"They ask you about giving: say, 'The charity you give shall go to the parents, the relatives, the orphans, the poor, and the traveling alien.' Any good you do, God is fully aware of." Quran [2:215]

It is important to point out that payment of Zakah is not restricted to individuals. Corporations are also expected to pay Zakah, and they must do so even if one or more of the partners in the corporation does not possess the Nisab. In the latter case, they are still required to pay Zakah if the assets of their jointly owned corporation exceed the Nisab. In this case, the partner not possessing the Nisab must pay Zakah in proportion with his share in the capital of the corporation. ${ }^{26}$ In effect, Zakah not only takes care of the neediest members of society, it also circulates the wealth in the society and makes sure that the gap between the different classes is not as large as it otherwise would be.

This does not mean, however, that Muslims are not allowed to become wealthy and must give everything they do not use for their essential needs as constant payment of Zakah. Muslims believe that Zakah attracts God's special blessing and their wealth will be multiplied after they have paid Zakah. That is why most Muslims are generally enthusiastic about giving.

"Any charity you give will be repaid to you, without the least injustice." Quran [2:272]

At the same time, a Muslim who possesses the Nisab but is barely able to pay his or her own bills, calculates the amount for Zakah only after having fulfilled all of his or her own financial obligations. ${ }^{27}$

"They ask you about intoxicants and gambling: say, 'In them there is a gross sin, and some benefits for the people. But their sinfulness far

24. See id. (explaining that if a Muslim's wealth exceeds the Nisab, s/he becomes eligible to be a Zakah payer under Islamic Law).

25. Id. (noting that Zakah is given as a percentage of total wealth, usually $2.5 \%$ of the annual surplus income plus the total surplus assets).

26. MuHAMmad TAQI USMani, AN INTRODUCtION TO Islamic FinanCE 106 (2002).

27. ANGELA WOOD, RELIGION FOR TODAY: ISLAM FOR TODAY 24 (1998). 
outweighs their benefit.' They also ask you what to give to charity: say, 'The excess.' GOD thus clarifies the revelations for you, that you may reflect." Quran [2:219]

Zakah does not necessarily have to be paid in money. Zakah can be paid in the form of agricultural products, specifically in the form of food for the hungry.

"O you who believe, you shall give to charity from the good things you earn, and from what we have produced for you from the earth. Do not pick out the bad therein to give away, when you yourselves do not accept it unless your eyes are closed. You should know that Allah is Rich, Praiseworthy." Quran [2:267]

\section{E. Sadaqah}

Sadaqah can be defined as small daily acts of charity. This can be in the form of small amounts of money given to the poor but also practical acts, such as helping a foreigner find his way or carrying a load for an elderly person. Strictly speaking, there is no obligation to give Sadaqah. However, throughout the Quran, God encourages Muslims to give Sadaqah to the needy whenever they can, by stressing the generous multiplication of rewards for those who freely give of their assets and time.

"The example of those who spend their monies in the cause of GOD is that of a grain that produces seven spikes, with a hundred grains in each spike. GOD multiplies this manifold for whomever He wills. GOD is Bounteous, Knower." Quran [2:261] ${ }^{29}$

In contrast to Zakah, there is no specific time or amount required by the Quran for giving Sadaqah. ${ }^{30}$ Although Sadaqah is only a modest gift for someone in need, ${ }^{31}$ the prophetic Sunnah of Muhammed is filled with stories about rewards in the Hereafter for those who give Sadaqah. However, not every gift given to a needy person is a Sadaqah. There are requirements for Sadaqah to lead to a reward in the Hereafter. The one and only purpose of Sadaqah should be the desire to please God by helping someone in need. Therefore, giving Sadaqah in order to draw attention to one's wealth does not attract a reward. In fact, under Islam, simple kind words and just treatment of people is better than giving Sadaqah followed

28. Sadaqah also appears as Sadaka and Sadakah (plural: Sadaquat or Sadakat). Sadaqah is derived from the Arabic root (S-d-q). Derivations of the root include Sadiq (honest), Siddiq (virtuous), and Sidk (honesty and sincerity). The hallmark of a sincere Muslim is sharing one's wealth with the needy.

29. Rashad Khalifa, The Authorized English Translation of the Quran, SUBMISSION.ORG, http:/www.submission.org/suras/sura2.htm (last visited Mar. 24, 2011).

30. HARMSEN, supra note 19.

31. There is no obligation to restrict Sadaqah to Muslims; it can be given to Jews or Christians as well. 
by humiliation or insult to its recipient. ${ }^{32}$

Embarrassing the recipient of a Sadaqah by reminding him of the Sadaqah that he has been given, or by somehow implying that he now owes something in return, immediately cancels any chance of reward.

"Oh you who believe, do not nullify your charities by inflicting reproach and insult (on the receivers of your charity), like him who spends his wealth to be seen by others, and he believes not in God and the Last Day." Quran [2:264]

"They, who spend their wealth for the cause of God, then do not follow up what they have spent with taunt or injury, for them is their reward with their Lord, and they shall have no fear, nor shall they grieve." Quran [2:262]

For this reason, the Quran encourages Muslims to give their Sadaqah anonymously to ensure that the Sadaqah was made with the pure intention of helping the needy and pleasing God rather than to seize the attention of others.

"If you announce your charities, they are still good. But if you conceal them, and give them to those who really need them, it is better for you and God remits more of your sins. GOD is fully aware of everything you do." Quran [2:271]

Similarly, the Prophet Muhammad (P) said: "Seven people Allah will shade in His shade on the day when there is no shade except His." Among the seven he mentioned was "a man who gave something in charity secretly such that his left hand did not know what his right hand had given" (Bukhari).

A Sadaqah does not have to be a financial gift. ${ }^{33}$ The Prophet Muhammad (P) said, "To smile in the company of your brother is a Sadaqua" (Bukhari). If a Muslim does not have enough money to give a financial Sadaqah, he or she can give a Sadaqah by helping others or simply by refraining from evil doing. ${ }^{34}$ Thus, visiting orphanages and retirement homes merely to share the joy and misery of the less fortunate is also a Sadaqah that guarantees a reward in the Hereafter.

Some opponents of early Islam, in an attempt to justify their miserliness, argued that usury increases one's wealth while Sadaqah only

32. Quran 2:263 ("A kind word with forgiveness is better than almsgiving followed by an insult.").

33. Tallal Alie TuRfe, UNITY IN IsLam: Reflections AND Insights 132 (2004).

34. Sahih Al-Bukhari, Volume 2, Hadith 524 (Abu Musa narrated that the Prophet said, "Every Muslim has to give in Sadaqah." The people asked, "But what if someone has nothing to give?" He said, "He should work with his hands and benefit himself and also give Sadaqah (from what he earns)." The people further asked, "If he cannot do even that?" He replied, "Then he should help the needy who appeal for help." Then the people asked, "If he cannot do that?" He replied, "Then he should perform all that is good and keep away from all that is evil and these will be regarded as charitable deeds."). 
diminishes it. But the Quran emphasizes that although usury increases one's wealth in life, it does not bring any benefit in the Hereafter, and what increases one's credit in the Hereafter is paying charities or Sadaqah. ${ }^{35}$

\section{Caring for Orphans and for the Needy}

Although adoption is prohibited in Islam, taking care of orphans and children who have been abandoned by their parents is highly encouraged. "Taking care" of orphans does not only refer to financial care; it also refers to emotional care and support. Many prophetic Hadiths encourage taking care of orphans and promise Muslims huge rewards from God in return. One example is the Hadith transmitted by Sahl ibn Sa'd (may Allah be pleased with him) that the Prophet Muhammad (P) said, "Myself and the one who takes care of an orphan, will be together in Paradise like this," and he raised his forefinger and middle finger together, leaving little space between them (to show how close they will be in Paradise) (Bukhari).

Not just orphans, but anyone who is needy, regardless of race, religion or gender, should be taken care of. There is an obligation on every Muslim to look after any member of the society who is less fortunate. The Prophet Muhammad (P) said, "[A] person is not a true Muslim if he or she eats to his or her fill while knowing that the neighbor is hungry" (Bayhaqi).

\section{Fair Trade, Fulfilling Covenants, and Free Competition}

'Abdullah bin 'Umar (may Allah be pleased with him) narrated that the Prophet Muhammad (P) said, "Do not urge someone to return what he has already bought from another seller in order to sell him your own goods instead" (Bukhari). These are the ethics of doing business in Islam. Muslims are not allowed to snare customers away from their competitors after the completion of a deal. It is different if there is free competition and one business is making better offers than another. The customers are freely choosing to do business with the one who makes the best offers. But, once a deal has been made, Islam prohibits Muslim traders from overturning the deals concluded by their competitors in order to claim the business and the profits for themselves.

' $O$, you who believe, do not eat up each others' properties in vanities, but let there be amongst you traffic and trade by mutual consent, nor kill or destroy yourselves, verily God has been most merciful to you." Quran [4:29]

"... Observe fully the measure and the balance, and do not cheat the people of their goods, and do not cause corruption on the earth after its

35. Quran 30:39 ("The usury that is practiced to increase some people's wealth, does not gain anything at GOD. But if you give to charity, seeking God's pleasure, these are the ones who receive their reward manifold."). 
restoration. That is better for you, if you are faithful." Quran [7:85]

The Prophet Muhammad (P) further emphasized the previous Quranic verse in the following words: "[A] sale is a sale only if made through mutual consent" (Ibn Majah). Truthfulness in business dealings is central to doing business under Islamic Law. The Prophet Muhammad (P) said, "Truthfulness leads to righteousness and righteousness leads to Paradise ... . Falsehood leads to wickedness and wickedness leads to the hell fires" (Bukhari). Hence, the fulfillment of one's obligations and promises is one of the fundamental rules laid down by the Quran. [5:1]

"O you who believe, you shall fulfill your covenants ...." Quran

\section{Fair Treatment of Workers}

Abdallah bin 'Umar (may Allah be pleased with him) narrated that the Prophet Muhammad (P) said, "Give the worker his wages before his sweat dries up" (Ibn Majah). Other Prophetic Hadiths in this context include: "I will foe to three persons on the day of judgment, one of them being the one who does not give him his due when he employs a person who has accomplished his duty," and "Your workers/servants are your brothers. They should eat from what you eat and dress like you dress and let them not bear a burden that they cannot bear, then lend your help to them." Generally, the concept of brotherhood is emphasized in the Quran as an indispensable principle in Islam.

"The believers are but brothers, so make settlement between your brothers. And fear Allah that you may receive mercy." Quran [49:10]

\section{F. Baitul Mal ${ }^{36}$}

One of the most interesting ideas in this regard is the idea of "Baitul Mal." Literally, it means "the house of wealth." Technically, Baitul Mal is the public treasury or "the Exchequer of an Islamic State., ${ }^{, 37}$ It was first established by the Prophet Muhammad (P) and was then further developed at the time of Caliph Omar Ibn el Kattab (May God be pleased with him). The idea of Baitul Mal is similar to that of an insurance company. ${ }^{38}$ It was where the revenues of the state were collected and where any citizen facing a financial crisis found sanctuary. Baitul Mal constituted a pool where all taxes were collected and spent whenever a citizen needed financial help.

36. See generally Holger Weiss, Zakat and the Question of Social Welfare: An Introductory Essay on Islamic Economics and Its Implications for Social Welfare, in SOCIAL WelFARE IN MUSLIM SOCIETIES IN AFRICA 7, 17-18 (Holger Weiss ed., 2002).

37. EDWIN E. HITTI, BASIC MECHANICS OF IsLAMIC CAPITALISM IV (2007).

38. MuHAMmad AKRAM Khan, IsLamic ECONOMics and FinanCE: A Glossary 32 (2d ed. 2003). 
The revenues of Baitul Mal included that from Al Zakah (mandatory charity), Al Sadaquat (voluntary charities), Al Ushr (the tithe or import tax), Al Khums (the fifth), ${ }^{39} \mathrm{Al}$ Jizyah (a poll tax), ${ }^{40} \mathrm{Al}$ Kharaj (a tax on land and agricultural products), Al Fay (spoils accruing to Muslim armies without a war) ${ }^{41}$ and the wealth of those who have no heirs.

As for those who were entitled to receive money from the Baitul Mal, the Holy Quran defines them in the following verse:

"[T] the poor, the needy, the workers who collect (the charities), the new converts, to free the slaves, to those burdened by sudden expenses, in the cause of GOD, and to the traveling alien. Such is GOD's commandment. GOD is Omniscient, Most Wise." Quran [9:60]

Accordingly, Baitul Mal also served for the redistribution of wealth to achieve a balance between the rich and the poor and to diminish the gaps between the classes of society. Most Muslims believed that money in Baitul Mal was God's property and the ruler was no more than its manager and protector. ${ }^{42}$ To make sure that the property of God inside Baitul Mal was safe, Baitul Mal was subject to the supervision and control of Diwan al Zimam. ${ }^{43}$ Thus, Baitul Mal was one of the first social solidarity institutions in the world. Unfortunately, the idea of Baitul Mal has vanished from most Islamic countries.

39. Quran 8:41(These are the spoils of war that the Muslims won after actual fighting with an enemy. Four-fifths of the spoils go to the winning army and one-fifth goes to Baitul Mal as property of God and his Apostle. "And know that out of all the booty that ye may acquire (in war), one-fifth shall go to GOD and the messenger, and to his near relatives, the orphans, the needy, and the wayfarer, if ye do believe in God and in the revelation We sent down to our servant on the day of the decision, the day the two armies clash. For God hath power over all things.").

40. History of Humanity: Volume IV: From the SEVENTH to the SixteEnth CEnTURY 321 (M.A. Al-Bakhit et al. eds., 2000). This is also known as the "protected people's tax." This tax was paid by the Christians and Jews and all other non-Muslims living in the Islamic State. While Muslims paid their taxes in the form of Zakah, the nonMuslims paid their taxes in the form of Jizyah. Not all non-Muslims were obliged to pay the Jizyah. Women, children, priests, elderly, slaves, the mentally ill, and all those who could not afford it were exempt from paying Jizyah.

41. Quran 59:7 (explaining that Al Fay is what the opponent left behind voluntarily, either in fear of being attacked or just for the impossibility of taking it along) (The revenues accruing from Fay were to be distributed according to the verses of the holy Quran as follows: "Whatever Allah has given to His Messenger as spoils from the people of the towns is for Allah and for the Messenger and for the near of kin and the orphans and the needy and the wayfarer, so that it may not circulate only among those of you who are rich.").

42. Weiss, supra note 36 , at 17.

43. Diwan Al Zimam was the bureau responsible for the auditing and supervision of the different state departments and officials. It is also known as Diwan Al Azimma. 


\section{ISLAM AND THE ENVIRONMENT}

The Prophet Muhammad (P) instructed Muslims to plant trees and regarded this act as a Sadaqah. Muslims were also instructed never to uproot the trees of the enemy during war. ${ }^{44}$ The rules of war in Islam include many restrictions on Muslim armies. It is fascinating that among these prohibitions is the uprooting of trees and the burning of books. These rules were regarded as of equal importance to the rules prohibiting the killing of women, children, the elderly, and unarmed men or "noncombatants." The fact that Muslims cannot uproot the enemy's trees even in war emphasizes the sacredness and importance that Islam accords to plant life and the environment.

Islamic law also includes rules regarding animals. The Sunnah is rich with Hadiths encouraging gentleness with animals. ${ }^{45}$ One of the Hadiths tells a story about a woman who was sent to the hell fires because of her cruelty to a cat, which she had locked up with no food or water until it died. Many Hadiths promise rewards to those who are gentle and compassionate to all of God's creatures on one hand and warn against cruelty and violence towards animals on the other. ${ }^{46} \mathrm{~A}$ verse in the Quran states that all the creatures that God has created are "nations" like humans, which means that their lives should be respected exactly as is human life. ${ }^{47}$ Even if humans have to kill animals to eat or to defend themselves, Muslims are required to kill the animal without unnecessary cruelty or torture. The Prophet Muhammad (P) said, "[I]f you must kill, kill without torture" (Bukhari). This Hadith came with no exception for venomous or hostile animals. ${ }^{48}$

In the Quran, God emphasizes the beauty of the earth as one of his most fascinating creations. He speaks about its many wonders and how the same soil that is watered by the same water brings up different crops side by side. As one of His great creations, God expects humans to appreciate

44. See Islamic Ethics of Life: Abortion, WaR, AND EutHanasia 97-172 (Jonathan E. Brockopp ed., 2003) (detailing the ethics of war in Islam).

45. Quran 6:38 ("Prophet Muhammad (P) was asked by his companions whether kindness to animals was rewarded in the hereafter. He replied: 'Yes, there is a meritorious reward for kindness to every living creature.").

46. Caging animals in inadequate environments, mutilating body parts of animals, and branding are all acts that are prohibited by Islamic Law. For example, this obviously prohibits poultry farming utilizing the notorious battery cages, as is widely practiced in many countries.

47. Quran 6:38 ("And there is not a creature on Earth, or a bird that flys with its wings, but are nations like you. We did not leave anything out of the record; then to their Lord they will be gathered.").

48. See BeSheer AHMEd MaSRI, ANIMALS IN ISLAM 20 \& 29 (1989) (explaining that Islamic Law provides details about the tools that should be used to slaughter animals) (For example, Muslims are required to use sharp knives to make the death of the animals less painful.). 
and look after it so that it would always be a reminder of his power and wondrous creations.

"There are, in the land, neighboring plots, gardens of vineyards, cornfields, palm trees in clusters or otherwise, all watered with the same water, yet We make some of them taste better than others, there are Signs in that for people who use their intellect." Quran [13:4]

God takes pride in His creation of the environment, not only the earth but also the sky, the water, ${ }^{49}$ the wetlands, the mountains, and all his creatures. He uses these creations throughout the Quran to challenge human power and show human weakness in comparison to His power. God instructs humans to look after His creation as his vicegerents or deputies. ${ }^{50}$ Therefore, any acts that destroy, directly or indirectly, the creations of God--such as dumping toxic wastes into rivers and oceans, manufacturing products that destroy the ozone layer, careless oil spills, hunting endangered species for pleasure, interfering in unnecessary or irresponsible ways with the ecosystem, and similar actions-are all considered illegal under Islamic law.

\section{COMMERCIALLY PROHIBITED ACTIVITIES UNDER ISLAMIC LAW}

\section{A. Al Riba (Usury)}

Riba literally means "interest,"51 and its prohibition is often misunderstood as preventing any charges above the principal of a loan. However, it is important to understand that Riba is only the exorbitant increase of the principal for no reason other than the passing of time. In pre-Islamic times, money lenders used to exploit the neediness of borrowers. The customer was obligated to pay interest in return for borrowing a sum of money. The interest accumulated over time and, if by the end of the term of the loan the borrower was not able to pay back the loan with the interest, in return for extending the term of the loan the accumulated interest became part of the principal and interest would now be charged on the higher sum. If the interest rate was exorbitant, this easily became a vicious circle, a black hole from which the borrower was never able to escape. And, since it was considered a crime, punishable by

49. Water in Islam is regarded as the "secret of life," and it is essential for washing off physical and spiritual impurities. Therefore, it is a sin to waste or pollute it because of its importance to the maintenance of the lives of all of God's creatures. See MAWIL IZzI DIEN, The ENVironmental Dimensions of ISLAM (2000) (detailing the treatment of the environment in Islam).

50. Quran 2:31("And when thy Lord said to the angels: 'I am about to place a vicegerent in the earth,' they said: 'Wilt Thou place therein such as will cause disorder in it, and shed blood?-and we glorify Thee with Thy praise and extol Thy holiness.' He answered: 'I know what you know not.'").

51. JAQUIR IQBAL, ISLAMIC FINANCE MANAGEMENT 100 (2009). 
imprisonment, if someone did not pay his or her debts, it often led not only to the financial ruin but also to the personal ruin of the customer. This is where the Quran introduced a clear prohibition. ${ }^{52}$ Riba must not give the lenders the power to exploit borrowers with no end.

" $O$ you who believe, you shall observe GOD and refrain from all kinds of usury, if you are believers." Quran [2:278]

"If you do not, then expect a war from GOD and His messenger. But if you repent, you may keep your capitals, without inflicting injustice, or incurring injustice." Quran [2:279]

"O you who believe, Devour not usury, doubling and quadrupling (the sum lent). Observe your duty to Allah, that you may be successful." Quran [3:130]

Islamic jurists generally agree that borrowers and lenders should share the profits and losses that result from investing the loans. They argue that fixed interest obligations assumed by the borrower regardless of whether the result of the investment is a profit or a loss is what makes Riba a manifestation of evil. The problem is that most Muslim jurists talk about profit and loss sharing even though loans are needed for purposes other than business investments. Most people need loans to buy houses or to obtain medical treatment for costly illnesses. In such cases, there is no profit to be expected that could be shared between the borrower and the lender. At the same time, it is not possible and was not intended by Islam that people should depend on the philanthropy or goodwill of others to buy their houses or obtain medical treatment. They need a solution that is both practical and in line with Islamic law.

Muslim jurists also generally agree that it is acceptable for there to be a price for the deferment of the payment of debt. One of these jurists is the very well-known and respected Ibn Rushd. ${ }^{53}$ The justification for the distinction between price increases caused by deferment and Riba is that in Riba the principal grows with no end, while increasing the price in return for deferment does not affect the principal. The price of the loan increases only until the borrower starts paying back the loan. As soon as payments are made, it starts shrinking immediately. In other words, Riba is an exorbitant interest rate payable at the end of the loan term. If it cannot be paid, the rate is added to the principle and the vicious circle continues.

By contrast, a more modest payment obligation toward principal and interest that is payable regularly during the loan period and reduces the amount payable at the end of the loan period is acceptable. This is a good way of finding financial help in times of need. There is no problem if the lender charges a fee for providing the service and covering his expenses.

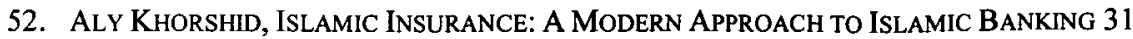
(2004).

53. IQBAL, supra note 51 , at 29 . 
The problem lies in the exploitation of weaker parties by exorbitantly high interest that puts the borrower in a worse situation after having gotten the loan.

"The usury that is practiced to increase some people's wealth, does not gain anything at GOD. But if you give to charity, seeking GOD's pleasure, these are the ones who receive their reward manifold." Quran [30:39]

It would be beyond the scope of this Article to apply these principles to the financial meltdown in the aftermath of the collapse of the American mortgage market. Suffice it to say that Islamic law does not oppose fair lending toward the purchase of a home as long as the borrower has to and is able to make regular payments that cover the cost of the loan (interest) and reduce the principal. However, Islamic law certainly stands in the way of predatory lenders that know full well that their clients will not be able to make their house payments once their adjustable rate mortgages (ARMs) move out of the initial phase during which an attractive-and often below market-rate was offered to attract the borrowers. Similarly, Islamic law does not allow interest-only mortgages. This author believes, arguably, society would not be experiencing the worst recession since World War II if Western capital markets had followed at least these basic principles of Islamic law.

\section{B. Al Gharar (Speculative Activites)}

Professor Mustafa Al Zarqa's definition of Gharar is "the sale of probable items whose existence or characteristics are not certain, due to the risky nature which makes the trade similar to gambling." 54 Most sales of futures options, forwards, and derivatives, as well as hedging operations, would fall under this definition. Gharar is not clearly prohibited in the Quran, ${ }^{55}$ but it is widely held that Gharar is prohibited by the Sunnah. The Prophet Muhammad (P) warned against ambiguous sales. The essence of the prohibition is the prevention of unfair surprises, that is, unexpected rights and obligations that distort the balance of a business agreement and result in hatred and disputes between the parties to such agreements. Therefore, the main aspects of all contracts must be clear and precise in order for the contract to be valid. Thus, the sale of fish yet to be caught or the sale of unborn animals is rendered invalid in Islamic law. ${ }^{56}$ The reason is, obviously, that the fish may never be obtained or the animal may never be born or may be born with defects.

The Prophet Muhammad (P) prohibited Gharar in order to prevent

54. Id. at 104.

55. KHORSHID, supra note 52, at 39

56. IQBAL, supra note 51, at 104. 
disputes and to protect the weaker parties to an agreement. The Western concept of clausula rebus sic stantibus is a related idea. Because of the very wide interpretation many Islamic scholars give to Gharar, namely that it prohibits any contracts about future uncertain events, even everyday insurance contracts, not just financial derivatives, are problematic in Islamic law. However, this is not entirely logical. It cannot be the intention of the prohibition of speculative contracts to prevent such useful instruments as automobile or health insurance. This point will be discussed more fully below.

\section{Al Maisir (Gambling)}

The word Maisir is derived from the Arabic root [yusr], ${ }^{57}$ which means "ease" or "convenience." Islam rejects any profits that are mainly the outcome of games of chance or luck. ${ }^{58}$ Thus, casinos, gambling, and lotteries are prohibited under Islamic Law. ${ }^{59}$

"They ask you about intoxicants and gambling: say, 'In them there is a gross sin, and some benefits for the people. But their sinfulness far outweighs their benefit.' They also ask you what to give to charity: say, 'The excess.' GOD thus clarifies the revelations for you, that you may reflect." Quran [2:219]

Maisir has only gradually come to be prohibited by Islam since it was an activity that was very strongly incorporated in the lives of many Arabs in pre-Islamic times. ${ }^{60}$ Thus, the above verse was sent down to the people as a first step in the prohibition process. The next verses are stricter and clearer about the prohibition of Maisir. It says that Maisir is an act of Satan that no Muslim should be involved in.

" $O$ you who believe, intoxicants, and gambling, and the altars of idols, and the games of chance are abominations of the devil; you shall avoid them, that you may succeed." Quran [5:90]

"The devil wants to provoke animosity and hatred among you through intoxicants and gambling, and to distract you from remembering GOD, and from observing the Contact Prayers (Salat). Will you then refrain?" Quran [5:91]

Maisir is known to distract humans from remembering God is in times of financial need. Instead of working hard and having faith in God to help them through the crisis, humans tend to spend the little money they have on gambling, trusting in the games of chance rather than in God's power.

57. BRIAN KeTtell, FreQuently ASKed Questions In IsLAMic FINANCE 114 (2010).

58. MUHAMMAD AYUB, UNDERSTANDING ISLAMIC FINANCE 112 (2007).

59. Id.

60. KETTELL, supra note 57. 


\section{Other Activities}

There are other activities that are discouraged under Islamic law. Monopolizing food in order to raise prices and maximize profits, while limiting the access of the poor to the food, is one of the most harshly punished activities under Islamic law. 'Umar Ibn Al Khattab (may Allah be pleased with him) reported that the Prophet Muhammad (P) said, "He who brings goods for sale is blessed with good fortune, but he who keeps them till the price rises is accursed" (Ibn Majah and Darimi).

Consumption of some products, like alcohol and drugs, is prohibited because they are unhealthy for the human body and mind. It follows that the sale and circulation of such products is also prohibited. Selling products that lead to the deterioration or destruction of the human mind or body is considered a sin. Therefore, all transactions related to these kinds of products are considered invalid. A corporation selling products considered unhealthy by Islam is considered to be spreading illness in society and is required to refrain from this activity. The Quran, in many verses, warns against unjust enrichment resulting from exploitation of the ignorance and inexperience of others.

"And do not eat up your property among yourselves for vanities, nor use it as bait for the judges, with intent that you may eat up wrongfully and knowingly a little of (other) people's property." Quran [2:188]

" $O$ you who believe, do not consume each others' properties illicitlyonly mutually acceptable transactions are permitted. You shall not kill yourselves. GOD is Merciful towards you." Quran [4:29]

The Sunnah is filled with Hadiths and stories about the exploitation of the inexperience or ignorance of others. One of the Hadiths was transmitted by Tawus Ibn 'Abbas (may Allah be pleased with him), who said that the Prophet Muhammad (P) said, "A town dweller should not sell the goods of a desert dweller on behalf of the latter" (Bukhari). This Hadith aims at protecting the inexperienced desert dweller from the manipulation of the town dweller who is more familiar with the market prices and may take advantage of the desert dweller's ignorance and inexperience in the market. Interestingly, a similar prohibition of the exploitation of inexperienced or ignorant parties can be found in several Western legal systems, including $\S 138$ (2) of the German Civil Code. ${ }^{61}$

61. Bürgerliches Gesetzbuch [BGB] [CIVIL CODE], Jan. 2, 2002, BUNDESGESETZBLATT [BGBL. I], as amended, §138, I 1-2 (Ger.), available at http://www.gesetze-im-internet.de/englisch_bgb/englisch_bgb.html\#BGBengl_000P138 (last visited Mar. 25, 2011) (Section 138 provides, "(1) A legal transaction which is contrary to public policy is void. (2) In particular, a legal transaction is void by which a person, by exploiting the predicament, inexperience, lack of sound judgment or considerable weakness of will of another, causes himself or a third party, in exchange for an act of performance, to 


\section{ISLAMIC ALTERNATIVES TO THE PROHIBITED ACTIVITIES AND THE ESTABLISHMENT OF ISLAMIC FINANCIAL INSTITUTIONS}

With all the prohibitions against various kinds of commercial dealings, in particular when broadly interpreted, Muslims became victims of the dichotomy between doing business with the West and following the commandments of Islam. This is why Islamic Financial Institutions (IFIs) came into existence. In Islamic countries, IFIs found fertile ground to grow. They offered alternatives to the commercial activities that are prohibited under Islamic law. Below is a brief summary of some of the business services offered by IFIs as alternatives to the previously mentioned prohibited activities.

\section{A. Al Murabaha (Cost-Plus Financing)}

Murabaha is an agreement between a bank and a client to purchase a certain product on behalf of the client with the intention to sell it to the latter for the same purchase price but on better terms. For example, if a client wants to buy a car but cannot pay the full purchase price immediately, the bank buys the car and sells it to the client in exchange for monthly or yearly installments or credit. In addition to the price, the client also pays the bank's expenses and an agreed upon profit, either a percentage or a fixed amount. ${ }^{62}$

In a Murabaha agreement, the customer is able to buy a product that he or she needs but cannot afford for a deferred price. Although the deferred price to be paid by the client is higher than the original purchase price, Murabaha is still consistent with Sharia. In a Murabaha agreement, the IFI is entitled to the original purchase price, the costs of the provision of its services, plus a reasonable fixed profit that is agreed upon between the parties. In this agreement, there is no exploitation of the weaker party and no risk of unfair surprise. It is merely a trade untainted by the risk that Riba pushes the borrower into a black hole of exorbitant interest obligations.

\section{B. Al Mudaraba (Trust Financing)}

In a Mudaraba contract, one of the parties provides the capital (the investor), and the other provides his or her work, expertise, and skills (Mudarib). ${ }^{63}$ The Prophet Muhamad and some of his companions were also Mudaribs. They traded with wealth that belonged to other investors and

be promised or granted pecuniary advantages which are clearly disproportionate to the performance.").

62. AHMEd AL-SUWAIDI, FINANCE OF INTERNATIONAL TRADE IN THE GULF 91 (1994).

63. See $i d$. at 73 for more information about Al Mudarba. 
shared the profits with them if profits materialized. ${ }^{64}$ Mudaraba is a way of doing business that does not excessively burden any of the parties. Profits and losses are shared equally. It is also possible that in a Mudaraba contract only profits are shared and any financial losses are completely borne by the investor. ${ }^{65}$ This is still an equitable deal and permitted by Islamic law because the burden sharing remains in effect with one side investing capital and the other investing labor and expertise.

\section{Al Musharaka (Profit Sharing)}

Literally, Musharaka means "to share." In the context of Islamic finance, however, Musharaka is a jointly-owned business, where the lender bears the risk together with the borrower. If the deal proves to be profitable, the lender and the borrower share the profits, but if it turns out to be a disappointment, they also share the loss. Musharaka obviously affords more protection to the borrower than interest-based loans that fix an interest rate regardless of whether the deal proves profitable or not. ${ }^{66}$ The risk is divided between the borrower and the lender and so are the loss and the profit.

\section{Al ljara (Leasing), Al Muquarada (Revenue Bonds), and Baiu Salam (Agricultural Financing)}

Under an Ijara agreement, a bank acquires a commodity that a client needs but cannot afford, with the intention to lease it to the client for use in his or her business at an agreed-upon rate. Usually the objects of such agreements are machines and vehicles. ${ }^{67}$ Muqarada bonds are issued by a bank and sold to investors to be invested in a project whose profits and losses are distributed among the shareholders. ${ }^{68}$

Baiu Salam is a contract of sale whereby the buyer pays the price of a certain commodity with specified qualities in advance. This kind of financing is most commonly used in the context of agricultural production. It is important to mention that such a sale comprises Gharar, since the object of the contract does not exist at the time the contract is concluded. The only reason why this contract would not be considered invalid is because there is no other way of financing the desired agricultural

64. Abdulla Saeed, Islamic Banking and Interest: A Study of the Prohibition of RIBA AND ITS CONTEMPORARY INTERPRETATION 51 (1996).

65. Id.

66. Id. at 61 .

67. Christine EnNew \& Nigel Waite, Financial Services Marketing: AN INTERNATIONAL GUIDE TO PRINCIPLES AND PRACTICE 195 (2007).

68. Angelo M. Venardos, Islamic Banking \& Finance IN South-East Asia: ITS DEVELOPMENT \& FUTURE 85 (2005). 
production. In other words, if the buyer did not provide the price in advance, the products would not come into existence.

\section{E. Takaful (Islamic Insurance)}

Each human being is subject to potential disasters, like a destructive storm, flood, or earthquake that leaves a person or corporation bankrupt, a sudden death that leaves a family without a provider, or an accident that causes a disability or other loss of income. The only protection against losses resulting from such disasters lies in insurance that mitigates, if not entirely eliminates, the loss and damages endured. But many Shariah scholars believe the way conventional insurance systems operate is inconsistent with Sharia since their business involves Riba, Maisir, and Gharar. ${ }^{69}$ Does this mean that Muslims have to bear all the risks and confront these disasters all by themselves in order to comply with the commandments of their religion? Obviously not.

In response, IFIs came up with an alternative to conventional insurance that, in their view, is more consistent with Islamic law. The idea of Takaful originated from what was known at the time of the Prophet Muhammad (P) as the "Aaqilah." The Aaqilah was a pooled fund to which all the members of a certain tribe made contributions to indemnify any member of their tribe who was struck by one of these disasters. ${ }^{70}$

Today, IFIs provide the same kind of service but call it "Takaful." Takaful literally means "solidarity." The way Takaful works is that a group of participants agree to pay monthly premiums in order to be insured in case of any misfortune and to help out their fellow Muslims in case any of them is the misfortunate one. ${ }^{71}$ The participants in a Takaful agreement enter the contract as both insured and insurer. Premiums are divided into two parts: one part goes to the indemnification of the participants and the other to be invested in any activity that is consistent with Sharia. ${ }^{72}$ The profits or losses resulting from such investment are shared among the Takaful participants and the IFI. ${ }^{73}$ The part of the premium that has been dedicated to the indemnification of the participants is also invested. However, these funds are distributed only to participants who have faced a calamity. ${ }^{74}$

The problem that many Muslim scholars have with conventional

69. Munammad Ayub, an Introduction to TaKaful-An alternative to INSURANCE 1, available at http://www.sbp.org.pk/departments/ibd/Takaful.pdf (last visited Mar. 24, 2011).

70. $I d$.

71. Id.

72. Id. at $1-2$.

73. Id. at 2 .

74. See AYUB, supra note 58, at $417-32$ for more information about Takaful, how it works, and how IFIs benefit from it. 
insurance companies seems to be the total shift of the risk to the insurance company. Since the clients are not shareholders or risk bearers of the insurance company, they have certainty over the cost of the transaction, while the insurance company has uncertainty about the claims it will need to satisfy. In other words, the Maisir or gambling part of such transactions is the possibility that an insured party may pay only one or two monthly installments before disaster strikes and then receive the entire value of the insurance policy. Alternatively, another insured party may pay monthly installments all her life, never have an accident, and, therefore, never get back any of the money she has invested. ${ }^{75}$

However, that is the same as what happens in the Aaqila, which has been operational since the time of the Holy Prophet and has never been seriously criticized. A system where all the members of a tribe make contributions but only those who were affected by disaster received payments has all the characteristics of Western insurance companies. Is there not the same amount of Gharar or uncertainty about who will face the disaster and thus need the funds? Is there not Gharar about the amount of funds needed to cover the damage that will occur? Is there not Maisir or gambling in the fact that a member may pay for many years and never get anything in return and another may pay only for a month and be indemnified in full from the money that other Muslims have invested in the Aaqila?

In this author's opinion, and with all due respect to the creators of this system, if what makes conventional insurance incompatible with Sharia is the Maisir and the Gharar, these factors are also present in Takaful and Aaqila. Additionally, since an activity would only be considered allowed under Islamic law if the insured and the insurer share the losses as well as the profits resulting from the investment of the premiums, then Takaful is not insurance. If the insured may lose their funds that they have invested in an IFI, sharing the losses as well as the profits, then how are they insured? Is it consistent with Islamic law that Muslims pay premiums to protect their businesses and families against disasters and the IFI loses its contributions and, hence, its protection in bad business transactions?

Moreover, in a Takaful agreement, there is a "donation clause" to the effect that the accumulated premiums of a participant will be donated to another in case the other is the one who faces the hazard first. ${ }^{76}$ But again, this is not insurance if the insured is required to donate his or her investment and may subsequently be confronted with the fact that all previously paid premiums have been expended because he or she was not among the first to face the calamity. And if Takaful "embodies the elements of shared responsibility, common benefit and mutual

76. AYUB, supra note 58 , at 421 . 
solidarity[,] ${ }^{, 77}$ does conventional Western insurance not offer the same advantages? Unsurprisingly, there was never a consensus of opinions among Muslim scholars that conventional insurance is prohibited under Islamic law. In fact, many Muslim scholars regard conventional insurance as a necessity in today's business world. ${ }^{78}$

\section{F. Al Quard Al Hassan}

Al Quard Al Hassan is an interest-free loan. The sole obligation of the borrowers of a Quard Hassan is to repay the amount of the loan. Most IFIs limit such interest-free loans to the needy. ${ }^{79}$ The capital for such loans usually originates from the Zakah and Sadaqah deposited previously at the IFIs by other wealthy Muslims. The Quran emphasizes the idea of the Quard Hassan several times. It encourages Muslims to give loans with lenient repayment terms and not claim back the money at all if possible.

"If the debtor is unable to pay, wait for a better time. If you give up the loan as a charity, it would be better for you, if you only knew." Quran [2:280]

The Prophet Muhammad (P) in many of his Hadiths also encouraged giving interest-free loans to the needy. The Prophet Muhammad (P) specifically told lenders not to claim their money back if they can afford such generosity and they feel that claiming back the loan would excessively burden the borrower. Jabir bin 'Abdullah (may Allah be pleased with him) narrated that the Prophet Muhammad (P) said, "May Allah's mercy be on him who is lenient in his buying, selling and in demanding back his money" (Bukhari).

\section{IMPLICATIONS FOR DOING BUSINESS IN AND WITH ISLAMIC COUNTRIES}

The Islamic values discussed above are translated into prohibited and permitted commercial activities, which implicate the world of business. It must be remembered that Islam to Muslims is not just a faith; it is also the law that governs their lives and the way they choose to live their lives. Therefore, to find a Muslim who will conduct his or her business in a manner that contradicts Islamic law is rare. Important Muslim businessmen and women, small investors, and huge corporations alike are constantly worried that their businesses may comprise Riba or Gharar. Even average individuals, who cannot afford to buy themselves a car or a house and have to borrow the money from a bank, may have sleepless nights over the loan they had to take and the sin of Riba that they were forced to commit. A

77. $I d$.

78. Id. at $430-31$.

79. ENNEW \& WAITE, supra note 67, at 195. 
direct response to these prohibitions, as previously mentioned, is the appearance of IFIs, Islamic banks, and Islamic insurance companies.

However, some open-minded Muslim scholars have defended conventional banking and insurance systems, albeit with reservations against the abuse of inexperienced clients and excessive profits, as a necessity for the prosperity of the economies of Islamic countries, under the notion of Masaleh Mursala. This means that there has been no consensus opinion among Muslim scholars on the prohibition of conventional banking and insurance systems. Without consensus, however, the prohibition of dealing with Western banks and insurance companies does not become binding upon Muslims. This means that each Muslim can decide for herself whether to engage in these kinds of business practices. Some Muslims will enter into conventional banking and insurance contracts, which explains why Western banks and insurance companies are still operating profitably in most Islamic countries. From a business point of view, for example, Egyptian businessmen have found that rejecting conventional banks and insurance companies will only alienate business partners from non-Islamic countries and will lock them out of international markets. The same is true, of course, for other Islamic countries. Therefore, Western companies and individuals can usually find business partners in Islamic countries who understand that there is no prohibition of conventional banking and insurance, properly understood, in Islamic law.

As for businesses that deal in prohibited products, the matter is stricter. These prohibitions are clearly stated in the Quran and Sunnah, which are the primary and divine sources of Islamic law binding upon all Muslims. Thus, a wine business will not flourish in Islamic countries, nor will a business that sells and markets pork products. All members of Islamic society frown upon the sale of prohibited products. An investor is well advised to become aware of Islamic law on prohibited products before investing in ventures in Islamic countries. As previously stated, prohibited products are limited to pork, wine, and blood. Therefore, it is not difficult for an investor to avoid going wrong after brief research about the Islamic country in which he or she intends to do business.

\section{CONCLUSION}

The first and most important conclusion is that CSR, and all that it represents, is not only consistent with the Sharia, but actually lies at the very heart of it. Sharia is filled with trade rules that stress the concept of CSR. Because Islam is a faith in addition to a law, Muslims find these concepts stated in the Quran and Sunnah binding and impossible to circumvent once they correctly understand them. Thus, after taking a close look at the primary sources of the law, one finds that commercial ethics are 
much more highly regarded in Islamic commerce than in the Western world of business, where making profits is the ultimate goal. ${ }^{80}$

The unsupervised activities of the banks and allowing them to take over the financial markets in ways beyond the regulatory means of the state is the main reason in the current recession why gains were privatized while losses were socialized. ${ }^{81}$ One notices that if the commercial rules in Islamic law were more regarded in the West, at least some of the complications of the current financial crisis would not have taken place. However, although there are some prohibited commercial activities in Islamic law, like exploiting weaker parties in a contractual relationship, there are also many other activities that have been incorrectly dragged under the column of "prohibited activities." Loans, for instance, can be a good way of financing urgent expenses.

Everyone understands that banks have to make profits and cover their expenses and, therefore, cannot offer loans as a benevolent activity. Since Muslim scholars have agreed that the increase of the price is allowed in return for the deferment of payment, this author fails to see why Sharia would prohibit these loans. If they help the borrowers without exacerbating their financial troubles, is this not in the interest of Muslim society? A loan that helps the borrower afford a home (without getting into a vicious circle of interest and debt) is actually encouraged by Islamic law, the main objective of which is the welfare of humans. There is no reason for a socially responsible bank to be frowned upon by Islamic society. This is true as long as the bank gives loans to its clients for a reasonable price for deferring the payment and offers feasible payment terms without fixing an exorbitant interest rate.

Likewise, IFIs may not be Islamic if they do not regard CSR rules and if they only aim to invent business opportunities by calling their businesses "Islamic." In other words, some IFIs try to circumvent Sharia by giving the prohibited activities different names. There are many Quranic verses and Prophetic Hadiths that encourage Muslims to understand the law correctly without prohibiting what God has made lawful to them.

" $O$, you who believe, Do not forbid the good things that God has made lawful for you and do not transgress, For God does not love the transgressors." Quran [5:87]

Thus, when learning the Quran and Sunnah, a Muslim should consider the overall spirit of Sharia. This means that the outcome can never be against the public interest of Islamic society in the long term. To make the lives of Muslims easier, God has included in the Quran certain verses

80. Sallyanne Decker \& Christopher Sale, An Analysis of Corporate Social Responsibility, Trust and Reputation in the Banking Profession, in Professionals' PERSPECTIVES OF CORPORATE SOCIAL RESPONSIBILITY 152 (Samuel O. Idowu \& Walter Leal Filho eds., 2009).

81. See id. 
that give an overview of the spirit of Sharia in order to help the faithful decide about issues that come up after the legislation process is over.

"Say: The things that my lord has indeed forbidden are the shameful deeds, whether (committed) publicly or in secret; sins and trespasses against truth or reason." Quran [7:33]

This verse states that any trespasses against truth or reason, like attempts at exploitation or deception and any acts of injustice, are prohibited in Islamic law. Finally, the essence of most of the prohibitions of the Islamic law, which came down to attain the welfare of its followers, is this:

"We have not sent you (Muhammad), except out of mercy from us towards the whole world." Quran [21:107] 